\title{
STUDI KRITIS MINUMAN TEH KOMBUCHA: MANFAAT BAGI KESEHATAN, KADAR ALKOHOL DAN SERTIFIKASI HALAL
}

\author{
Priyono $^{1}$, Dody Riswanto ${ }^{2}$ \\ Fakultas Sains, Farmasi dan Kesehatan, Universitas Mathla'ul Anwar Banten ${ }^{1}$ \\ Fakultas Keguruan dan Ilmu Pendidikan, Universitas Mathla'ul Anwar Banten ${ }^{2}$ \\ J1. Raya Labuan KM 23 Kec. Saketi Kab.Pandeglang Banten, Indonesia \\ Korespondensi Author: aura.priyono@gmail.com
}

\begin{abstract}
Kombucha tea has become a trendy drink and is in demand by consumers because it has many health benefits. However, the fermentation of kombucha also produces ethanol or alcohol. Halal status has become a global issue. No exception for kombucha tea products. The purpose of this study was to examine the health benefits, alcohol content and halal certification of kombucha tea. The method approach used is the literature study method. The results of the study indicate that kombucha tea is a fermented drink that has an effect on the health of the human body by having biological activities such as antioxidants, antimicrobials, antidiabetic, anticancer, hepaprotective and anti-inflammatory properties. The alcohol content in kombucha tea can be consistently below $0.5 \%$ if the kombucha manufacture meets certain standard and standard processes. Kombucha tea in Indonesia has products that have received halal certification.
\end{abstract}

Keywords: Alcohol, Health, Kombucha, Halal

Abstrak: Teh kombucha telah menjadi minuman tren dan diminati konsumen karena memiliki banyak khasiat bagi kesehatan. Namun hasil fermentasi kombucha juga menghasilkan etanol atau alkohol. Status halal sudah menjadi suatu isu global, tak terkecuali untuk produk teh kombucha. Tujuan dari penelitian ini adalah mengkaji manfaat untuk kesehatan, kadar alkohol dan sertifikasi halal dari teh kombucha. Pendekatan metode yang digunakan yaitu metode studi literatur. Hasil kajian menunjukkan bahwa teh kombucha merupakan minuman fermentasi yang memiliki efek bagi kesehatan tubuh manusia dengan memiliki akivitas biologis seperti antioksidan, antimikroba, antidiabetes, antikanker, hepaprotektif dan antiinflmasi. Kadar alkohol pada teh kombucha bisa konsisten dibawah 0,5\% jika pembuatan kombucha memenuhi proses-proses tertentu yang telah standar dan baku. Teh kombucha di Indonesia sudah ada produknya yang telah mendapatkan sertifikasi halal.

Kata Kunci : Kadar Alkohol, Kesehatan, Kombucha, Halal

\section{PENDAHULUAN}

Teh kombucha merupakan produk minuman menyegarkan dan menyehatkan yang memiliki rasa sedikit manis dan asam, yang dihasilkan melalui proses fermentasi selama 7-21 hari dari larutan teh dan gula menggunakan berbagai kultur bakteri (Acetobacter xylinum, A. xylinoides, Bacterium gluconicum) dan jamur (Saccharomyces cerevisiae, S. ludwigii, Zygosaccharomyces bailii, Z. rouxii, Schizosaccharomyces pombe, Torulaspora delbrueckii, 


\section{IJMA: International Journal Mathla'ul Anwar of Halal Issues}

Volume 1 Nomor 1- Maret 2021

Brettanomyces bruxellensis, B. lambicus, B. custersii, Candida sp., or Pichia membranaefaciens) yang dikenal SCOBY (symbiotic culture of bacteria and yeast) (Kaewkod et al., 2019)

Kombucha asal mulanya dari Manchuria pada dinasti Tsin (220 SM) yang digunakan sebagai minuman detoks dan energi. Pada tahun 414 M kombucha dibawa ke Jepang yang digunakan untuk menyembuhkan masalah pencernaan Kaisar Inkyo. Dengan berkembangnya route perdagangan, kombucha (nama dagang Mo-Gu) menyebar ke Rusia (dengan nama Cainiigrib, Cainii kvass, Japonskigrib, Kambucha, Jsakvasska) dan kemudian menyebar ke wilayah Eropa yaitu Jerman (dengan nama Heldenpilz, Kombuchaschwamm) sampai abad ke 20. Pada masa perang dunia ke -2, kombucha di perkenalkan oleh Jerman dan pada tahun 1950 menyebar ke Prancis dan mendominasi dan populrr di Afrika Utara. Setelah perang dnia ke 2, teh kombucha oleh masyarakat Italia dikenal dengan minuman "Funkochinese". Pada tahun 1960 peneliti dari Swiss melaporkan bahwa meminum kombucha memiliki manfaat seperti makan yogurt sehinngaa konsumsi produk kombucha menjadi sangat popular. Pada abad ke-21 kombucha dijual hampir di seluruh dunia di berbagai toko retail dengan berbagai rasa (Jayabalan et al., 2014).

Pasar kombucha diestimasikan sebesar USD 1,5 milyar pada tahun 2018. Selama periode 2014-2018 market kombucha tumbuh sebesar 23\% pertahun. Di perkirakan akan terus tumbuh hingga mencapai USD 3,5-5 milyar pada tahun 2024 (Kim \& Adhikari, 2020). Di Indonesia kombucha dikenal sebagai jamur teh atau jamur dipo dan mulai populer dikonsumsi. Teh kombucha menjadi minuman tren dan diminati konsumen karena memiliki banyak khasiat bagi kesehatan antara lain sebagai antioksidan, antibakteri, memperbaiki mikroflora usus, dapat meningkatkan ketahanan tubuh dan menurunkan tekanan darah (Khaerah \& Akbar, 2019).

Khasiat tersebut dikarenakan adanya kandungan asam laktat, asam asetat, asam glukoronat, asam usnat, asam sitrat, asam oksalat, asam malat, asam glukonat, asam butirat, asam nukleat, asam kondroitin sulfat, dan asam hyaluronat merupakan kelompok asam yang terkandung dalam minuman teh kombucha. selain itu, minuman teh kombucha juga mengandung vitamin B1, B2, B6, B12, asam folat dan vitamin C, selain beberapa asam amino essensial, dan berbagai enzim penting yang memiliki banyak manfaat bagi tubuh (Ayu et al., 2020). Namun hasil fermentasi kombucha juga menghasilkan etanol atau alkohol (Herwin et al., 2013).

Status halal sudah menjadi suatu isu global, tak terkecuali untuk produk teh kombucha. Menurut ijtihad (Fatwa Majelis Ulama Indonesia Nomor: 10 Tahun 2018 Tentang Produk Makanan dan Minuman Yang Mengandung Alkohol/Etanol, 2018) yaitu produk minuman hasil fermentasi yang mengandung alkohol/etanol kurang dari 0,5\% hukumnya halal jika secara medis tidak membahayakan. Produk teh kombucha dikatakan halal tentu secara kualitas menunjukkan bahwa suatu produk teh kombucha dihasilkan dari rangkaian yang halal dari awal hingga akhir. Di dalam konteks supply chain, sebuah konsep 
halal mensyaratkan bahwa seluruh value chain dari raw materials produk teh kombucha sampai ke konsumen harus terjamin kehalalannya.

Hal inilah yang menjadi latar belakang pembuatan review artikel ini yang menitikberatkan pada pembahasan mengenai manfaat untuk kesehatan, kadar alkohol dan sertifikasi halal pada produk teh kombucha yang diharapkan bisa menambah kehati-hatian demi konsistensi status halal produk tersebut

\section{METODE}

Pendekatan metode yang digunakan yaitu menggunakan metode studi literatur. Data yang digunakan bersumber dari artikel jurnal, prosiding, dan konferensi, keputusan/Fatwa dan situs resmi yang memiliki hubungan atau kata kunci yang sesuai dengan topik kajian. Pencarian data dilakukan dengan instrumen pencari secara online menggunakan Pubmed, Sciencedirect dan Google scholar. Pencarian dilakukan dengan menggunakan kata - kata kunci "halal", "kombucha" dan alkohol". Penelusuran lebih lanjut dilakukan secara manual pada pustaka yang relevan.

\section{HASIL DAN PEMBAHASAN}

\section{Manfaat Teh Kombucha untuk Kesehatan}

Teh kombucha telah diklaim oleh pengkonsumsi teh kombucha dari seluruh dunia sebagai minuman yang memiliki efek bagi kesehatan tubuh manusia. Minuman teh kombucha disebut sebagai minuman pendukung kesehatan karena minuman ini terbukti memberikan dampak positif bagi fisiologis tubuh manusia. Minuman teh kombucha memiliki kandungan yang beragam yang berasal dari adanya proses biokimia yang dilakukan oleh kultur SCOBY yang terkandung di dalamnya dan bergantung dari bahan dasar yang digunakan untuk pembuatan minuman teh kombucha. Teh mengandung polifenol, flavonol, katekin, kafein, katekin galat, adenin, theobromin, theophilin, asam galat, tanin, dan gallotannin, yang memiliki sifat antioksidan tinggi yang mampu menangkal radikal bebas yang ada di tubuh manusia. Menurut United State Food and Drug Administration (FDA), teh kombucha merupakan minuman yang aman dikonsumsi karena telah lolos uji patogen dan uji klinis (Ayu et al., 2020). Beberapa aktivitas biologi dari minuman kombucha yang diteliti yaitu:

\begin{tabular}{cc} 
Tabel 1. Manfaat Kombucha bagi Kesehatan \\
\hline $\begin{array}{c}\text { Aktivitas } \\
\text { Biologi }\end{array}$ & Referensi \\
\hline Antioksidan & (Kaewkod et al., 2019), \\
& (Jayabalan et al., 2014), \\
& (Khaerah \& Akbar, 2019), \\
& (Ayu et al., 2020), (Gaggìa et \\
& al., 2019),(Jakubczyk et al., \\
\hline
\end{tabular}




\begin{tabular}{|c|c|c|}
\hline$(A)=$ & IJMA: Interr & $\begin{array}{l}\text { tional Journal Mathla'ul Anwar } \\
\text { Volume } 1 \text { Nomor 1- Maret } 2021\end{array}$ \\
\hline & & $\begin{array}{l}\text { 2020),(Hassmy et al., 2017), } \\
\text { (Puspitasari et al., 2017), (Tan } \\
\text { et al., 2020), (Aloulou et al., } \\
\text { 2012),(Kaewkod et al., 2019), } \\
\text { (Watawana et al., 2015), } \\
\text { (Kapp \& Sumner, 2019) }\end{array}$ \\
\hline & Antimikroba & $\begin{array}{c}\text { (Jayabalan et al., 2014), } \\
\text { (Gaggìa } \text { et al., 2019), (Tan et } \\
\text { al., 2020), (Yanti et al., 2020), } \\
\text { (Effendi et al., 2014), } \\
\text { (Jayabalan et al., 2014), } \\
\text { (Watawana et al., 2015), } \\
\text { (Kapp \& Sumner, 2019) }\end{array}$ \\
\hline & Antidiabetes & $\begin{array}{l}\text { (Aloulou et al., 2012), } \\
\text { (Kaewkod et al., 2019), } \\
\text { (Zubaidah } \text { et al., 2019), } \\
\text { (Watawana et al., 2015), } \\
\text { (Kapp \& Sumner, 2019) }\end{array}$ \\
\hline & Antikanker & $\begin{array}{c}\text { (Jayabalan et al., 2014), } \\
\text { (Aloulou et al., 2012), } \\
\text { (Jayabalan et al., 2014), } \\
\text { (Villarreal-Soto et al., 2019), } \\
\text { (Watawana et al., 2015), [23] }\end{array}$ \\
\hline & $\begin{array}{l}\text { Hepatoprotekt } \\
\text { if }\end{array}$ & $\begin{array}{l}\text { (Jayabalan et al., 2014), } \\
\text { (Abshenas et al., 2012), } \\
\text { (Watawana et al., 2015), } \\
\text { (Kapp \& Sumner, 2019) }\end{array}$ \\
\hline & Antiinflamasi & $\begin{array}{c}\text { (Aloulou et al., 2012), } \\
\text { (Aloulou et al., 2012), } \\
\text { (Villarreal-Soto et al., 2019), } \\
\text { (Watawana et al., 2015), } \\
\text { (Kapp \& Sumner, 2019) }\end{array}$ \\
\hline
\end{tabular}

Beberapa penelitian menunjukkan bahwa aktivitas biologi kombucha yaitu antioksidan, antimikroba, antidiabetes, antikanker, hepaprotektif dan antiinflmasi. Namun pengujian tersebut baru pada hewan uji atau in vitro secara laboratorium. Peneitian tentang hasil akvititas biologi langsung secara klinis pada manusia sangat susah ditemukan ((Watawana et al., 2015)). U.S. Food and Drug Administration and Kappa Laboratories, Miami, Florida, U.S.A melakukan pengujian dan tes biologi dan kimia dan melaporkan bahwa teh kombucha 
aman di konsumesi oleh manusia. Pengujian efek toksik teh kombucha pada tikus selama 90 hari menunjukkan tidak ada efek toksik pada tikus (Jayabalan et al., 2014).

Walaupun teh kombucha aman dikonsumsi, jika proses pembuatan kombucha tidak melalui proses yang standar serta menggunakan alat dan bahan yang tidak sesuai akan berdampak negatif bagi orang yang mengkonsumsinya.

2. Kadar Alkohol Teh Kombucha

Teh kombucha merupakan minuman hasil fermentasi sehingga dalam prosesnya akan menghasilkan alkohol dalam kadar tertentu karena, selama proses fermentasi, khamir $S$. cerevisiae memproduksi alkohol secara anaerob (gula pada media digunakan oleh $S$. cerevisiae nutrisi yang kemudian akan dirubah mejadi alkohol)(Pratiwi \& Aryawati, 2012).

Tabel 2. Hasil pengujian kadar alkohol pada teh kombucha

\begin{tabular}{cc}
\hline Kadar Alkohol & Referensi \\
\hline $0,0627292 \%$ & (Herwin et al., 2013) \\
\hline $1,61-5,12 \%$ & (Simanjuntak et al., 2016) \\
\hline $0,2-3,5 \%$ & (Jakubczyk et al., 2020) \\
\hline $0,06-1,95 \%$ & (Tan et al., 2020) \\
\hline $0,2973-0,6209 \%$ & (Pratiwi \& Aryawati, 2012) \\
\hline $0,7-1,3 \%$ & (Kapp \& Sumner, 2019) \\
\hline
\end{tabular}

Pada proses fermentasi kombucha umumnya pada hari ke empat sampai hari ke-12 terjadi peningkatan kadar alkohol Namun, setelah mengalami peningkatan pada hari ke-12 kemudian pada hari ke-16 mengalami penurunan kembali. Peningkatan kadar alkohol disebabkan karena, selama proses fermentasi, khamir S. cerevisiae memproduksi alkohol secara anaerob, kemudian alkohol menstimulasi pertumbuhan A.r xylinum untuk memproduksi asam asetat secara aerob, sedangkan asam asetat akan menstimulasi pertumbuhan S. cerevisiae. Kemudian alkohol digunakan oleh bakteri Acetobacter untuk pembentukan asam asetat, sehingga menyebabkan kadar alkohol mengalami penurunan (Pratiwi \& Aryawati, 2012).

Terdapat bermacam-macam pendapat mengenai status kehalalan alkohol. Beberapa berpendapat bahwa alkohol yang terdapat dalam suatu produk berapapun kadarnya, maka tetap dihukumi haram. Terdapat pula syarat kadar alkohol dalam produk, misalnya menurut Jabatan Kemajuan Islam Malaysia (JAKIM) yang membatasi halalnya produk jika mengandung alkohol maksimal 0,5 persen dan Association Researches for the Inspection and Certification of Food and Supplies (GIMDES) di Turki yang membatasi halalnya produk jika mengandung alkohol maksimal 0,3 persen.

Menurut ijtihad fatwa Majelis Ulama' Indonesia (MUI) Nomor 10 Tahun 2018 yaitu produk minuman hasil fermentasi yang mengandung alkohol/etanol kurang dari $0,5 \%$ hukumnya halal jika secara medis tidak membahayakan. Berdasarkan hasil kajian literatur 
pada beberapa penelitian menunjukkan bahwa kadar alkohol bisa mencapai lebih dari 0,5\% . Artinya tidak memenuhi syarat sebagai produk minuman halal.

Beberapa perusahan produsen kombucha menemukan beberapa cara untuk menurunkan kadar alcohol pada kombucha seperti dilakukan pengenceran, pasterurisasi panas, memfilter beberapa bakteri atau yeast yang memproduksi alkohol dan melakukan destilasi alkohol .sehingga didapatkan kadar alkohol pada kombucha dibawah 0,5\% (Kim \& Adhikari, 2020). Artinya produk teh kombucha bisa memenuhi syarat kadar alkohol jika dalam proses pembuatan kombucha memenuhi proses-proses tertentu yang telah standar dan baku sehingga produk kombucha yang dihasilkan konsisten dengan kadar dibawah 0,5\%

3. Sertifikasi Halal pada Produk Teh Kombucha

Memproduksi produk halal adalah bagian dari tanggungjawab perusahaan kepada konsumen muslim. Di Indonesia, untuk memberikan keyakinan kepada konsumen bahwa produk yang dikonsumsi adalah halal, maka perusahaan perlu memiliki Sertifikat Halal. Dewasa ini, konsumen muslim lebih sensitif dan sadar terhadap status kehalalan produk yang dibeli. Mereka cenderung memilih produk yang sesuai dengan prinsip syariat Islam yaitu dengan mencari produk halal. Untuk dapat mengetahui kehalalan produk salah satunya bisa dengan melihat adanya logo halal pada kemasan. Produk yang telah mencantumkan logo halal berarti telah lolos sertifikasi. Sertifikat halal adalah sertifikat yang menyatakan bahwa suatu produk (makanan, minuman, dan sebagainya) tidak mengandung unsur yang diharamkan, atau bahan baku dan pengolahan dilakukan dengan metode produksi yang sudah memenuhi kriteria syariat Islam.

Produk kombucha di Indonesia yang telah mendapatkan sertifikasi halal yaitu Localbrew dengan nomor sertifikasi halal yaitu 03120030851019 (Exp 23 Oktober 2021) adapaun produk nya berupa Dragon Fruit Kombucha Localbrew, Green Mix Kombucha Localbrew, Kiwi Kombucha Localbrew, Mango Kombucha Localbrew, Original Green Tea Kombucha Localbrew, Relaxing with Rosella \& Basil Seeds Kombucha Localbrew, Spices Kombucha Localbrew, Vinegar Kombucha Localbrew dan Yellow Mix Kombucha Localbrew (Majelis Ulama Indonesia, 2021)

Adanya produk teh kombucha yang mendapatkan sertifikasi halal di Indonesia artinya teh kombucha atau produk turunannya telah memenuhi persyaratan dan lolos kelayakan dan uji dari LPOM MUI berdasarkan acuan sertifikasi halal HAS 23000. yang merupakan persyaratan sertifikasi halal yang ditetapkan oleh LPPOM MUI guna sertifikasi halal suatu produk. Persyaratan tersebut berisi kriteria Sistem Jaminan Halal (SJH) dan persyaratan lain, seperti kebijakan dan prosedur sertifikasi halal. Terdapat 11 kriteria SJH yang dicakup dalam HAS 23000. Selain audit sesuai kriteria SJH (HAS 23000), LPPOM MUI juga akan memperhatikan aspek keamanan pangan, obat dan kosmetik sesuai dengan regulasi yang berlaku di Indonesia. 


\section{KESIMPULAN}

Teh kombucha merupakan minuman fermentasi yang memiliki efek bagi kesehatan tubuh manusia dengan memiliki akivitas biologis seperti antioksidan, antimikroba, antidiabetes, antikanker, hepaprotektif dan antiinflmasi. Kadar alkohol pada teh kombucha bisa konsisten dibawah $0,5 \%$ jika dilakukan pembuatan kombucha memenuhi proses-proses tertentu yang telah standar dan baku. Teh kombucha di Indonesia sudah ada produknya yang telah mendapatkan sertifikasi halal.

\section{DAFTAR PUSTAKA}

Abshenas, J., Derakhshanfar, A., Ferdosi, M. H., \& Hasanzadeh, S. (2012). Protective effect of kombucha tea against acetaminophen-induced hepatotoxicity in mice: A biochemical and histopathological study. Comparative Clinical Pathology, 21(6), 1243-1248. https://doi.org/10.1007/s00580-011-1273-9.

Aloulou, A., Hamden, K., Elloumi, D., Ali, M. B., Hargafi, K., Jaouadi, B., Ayadi, F., Elfeki, A., \& Ammar, E. (2012). Hypoglycemic and antilipidemic properties of kombucha tea in alloxan-induced diabetic rats. BMC Complementary and Alternative Medicine, 12(63), 1-9. https://doi.org/10.1186/1472-6882-12-63.

Ayu, K., Lestari, P., \& Sa'diyah, L. (2020). Karakteristik Kimia dan Fisik Teh Hijau Kombucha pada Waktu Pemanasan yang Berbeda. Journal of Pharmacy and Science, 5(1), 15-20. http://www.ejournal.akfarsurabaya.ac.id:80/index.php/jps/article/view/158.

Effendi, F., P. Roswiem, A., \& Stefani, E. (2014). Uji Aktivitas Teh Kombucha Probiotik Terhadap Bakteri Escherichia coli dan Staphylococcus aureus. FITOFARMAKA: Jurnal Ilmiah Farmasi, 4(2), 1-9. https://doi.org/10.33751/jf.v4i2.185.

Gaggìa, F., Baffoni, L., Galiano, M., Nielsen, D. S., Jakobsen, R. R., Castro-Mejía, J. L., Bosi, S., Truzzi, F., Musumeci, F., Dinelli, G., \& di Gioia, D. (2019). Kombucha beverage from green, black and rooibos teas: A comparative study looking at microbiology, chemistry and antioxidant activity. Nutrients, 11(1). https://doi.org/10.3390/nu11010001.

Hassmy, N. P., Abidjulu, J., \& Yudistira, A. (2017). Analisis Aktivitas Antioksidan Pada Teh Hijau Kombucha Berdasarkan Waktu Fermentasi Yang Optimal. PHARMACON, 6(4), 67-74. https://doi.org/10.35799/pha.6.2017.17719. 
Herwin, Kosman, R., \& Fitriani. (2013). Analisis Kadar Alkohol Produk Kombucha Daun Permot (Passiflora foetida L.) Asal Makassar Sulawesi Selatan Secara Kromatografi Gas. As-Syifaa, 05(02), 112-118. http://jurnal.farmasi.umi.ac.id/index.php/assyifaa/article/view/52.

Jakubczyk, K., Kałdú Nska, J., Kochman, J., \& Janda, K. (2020). Chemical Profile and Antioxidant Activity of the Kombucha Beverage Derived from White, Green, Black and Red Tea. Antioxidants, 9(447), 1-15. https://doi.org/10.3390/antiox9050447.

Jayabalan, R., Malbaša, R. v., Lončar, E. S., Vitas, J. S., \& Sathishkumar, M. (2014). A Review on Kombucha Tea-Microbiology, Composition, Fermentation, Beneficial Effects, Toxicity, and Tea Fungus. Comprehensive Reviews in Food Science and Food Safety, 13(4), 538-550. https://doi.org/10.1111/1541-4337.12073.

Kaewkod, T., Bovonsombut, S., \& Tragoolpua, Y. (2019). microorganisms Efficacy of Kombucha Obtained from Green, Oolong, and Black Teas on Inhibition of Pathogenic Bacteria, Antioxidation, and Toxicity on Colorectal Cancer Cell Line. Microorganisms. , 7(700), 1-18. https://doi.org/10.3390/microorganisms7120700.

Kapp, J. M., \& Sumner, W. (2019). Kombucha: a systematic review of the empirical evidence of human health benefit. Annals of Epidemiology, 30(2), 66-70. https://doi.org/10.1016/j.annepidem.2018.11.001.

Khaerah, A., \& Akbar, F. (2019). Aktivitas Antioksidan Teh Kombucha dari Beberapa Varian Teh yang Berbeda. Seminar Nasional LP2M UNM, O(0), 472-476. https://ojs.unm.ac.id/semnaslemlit/article/view/11466.

Kim, J., \& Adhikari, K. (2020). Current Trends in Kombucha: Marketing Perspectives and the Need for Improved Sensory Research. Beverages, 6(1), 1-19. https://doi.org/10.3390/beverages6010015.

Fatwa Majelis Ulama Indonesia Nomor: 10 Tahun 2018 Tentang Produk Makanan Dan Minuman Yang Mengandung Alkohol/Etanol, Pub. L. No. 10 tahun 2018, Majaleis Ulama Indonesia

(2018).http://www.halalmui.org/images/stories/Fatwa\%20Makanan\%20dan\%20Minuman\% 20Mengandung\%20Alkohol\%20(INA).pdf.

Majelis Ulama Indonesia. (2021). Daftar Belanja Produk Halal LPPOM MUI Pusat. Acuan Sertifikasi Halal HAS 23000. 
Pratiwi, A., \& Aryawati, R. (2012). Pengaruh Waktu Fermentasi Terhadap Sifat Fisik dan Kimia pada Pembuatan Minuman Kombucha dari Rumput Laut Sargasssum sp. / Maspari Journal, 04(1), 131-136. https://doi.org/10.36706/MASPARI.V4I1.1438.

Puspitasari, Y., Palupi, R., \& Nurikasari, M. (2017). Analisis Kandungan Vitamin C Teh Kombucha Berdasarkan Lama Fermentasi Sebagai Alternatif Minuman Untuk Antioksidan. Global Health Science (GHS), 2(3), 245-253. http://jurnal.csdforum.com/index.php/ghs.

Simanjuntak, D. H., Herpandi, \& Lestari, S. D. (2016). Karakteristik Kimia Dan Aktivitas Antioksidan Kombucha Dari Tumbuhan Apu-apu (Pistia Stratiotes) Selama Fermentasi Neliti. FishtecH Jurnal Teknologi Hasil Perikanan, 5(2), 123-133. https://www.neliti.com/id/publications/62170/karakteristik-kimia-dan-aktivitas-antioksidankombucha-dari-tumbuhan-apu-apu-pis.

Tan, W. C., Muhialdin, B. J., \& Meor Hussin, A. S. (2020). Influence of Storage Conditions on the Quality, Metabolites, and Biological Activity of Soursop (Annona muricata. L.) Kombucha. Frontiers in Microbiology, 12(11), 1-10. https://doi.org/10.3389/fmicb.2020.603481.

Villarreal-Soto, S. A., Beaufort, S., Bouajila, J., Souchard, J. P., Renard, T., Rollan, S., \& Taillandier, P. (2019). Impact of fermentation conditions on the production of bioactive compounds with anticancer, anti-inflammatory and antioxidant properties in kombucha tea extracts. Process Biochemistry, 83(8), 44-54. https://doi.org/10.1016/j.procbio.2019.05.004.

Watawana, M. I., Jayawardena, N., Gunawardhana, C. B., \& Waisundara, V. Y. (2015). Health, wellness, and safety aspects of the consumption of kombucha. In Journal of Chemistry (Vol. 2015, pp. 1-12). Hindawi Publishing Corporation. https://doi.org/10.1155/2015/591869.

Yanti, N. A., Ambardini, S., Ardiansyah, A., Marlina, W. O. L., \& Cahyanti, K. D. (2020). Aktivitas Antibakteri Kombucha Daun Sirsak (Annona muricata L.) Dengan Konsentrasi Gula Berbeda. BERKALA SAINSTEK, 8(2), 40. https://doi.org/10.19184/bst.v8i2.15968.

Zubaidah, E., Ifadah, R. A., Kalsum, U., Lyrawati, D., Putri, W. D. R., Srianta, I., \& Blanc, P. J. (2019). Anti-diabetes activity of Kombucha prepared from different snake fruit cultivars. Nutrition and Food Science, 49(2), 333-343. https://doi.org/10.1108/NFS-072018-0201. 
